\title{
Kajian Level dan Dampak Senyawa Polybrominated Diphenyl Ethers (PBDEs) pada Ikan Kerapu Budidaya dan Kerapu Liar dari Lampung
}

\section{Assessment of the Levels and Risk of Polybrominated Diphenyl Ethers (PBDEs) in Farmed and Wild Groupers from Lampung}

\author{
AGUS SUDARYANTO \\ Balai Teknologi Survei Kelautan, Badan Pengkajian dan Penerapan Teknologi \\ JI. MH. Thamrin 8, Jakarta \\ Email: agus.sudaryanto@bppt.go.id
}

\begin{abstract}
In regard to food security and safety, the need for evaluation of the risks and benefits of fishery products due to environmental contamination by polybrominated diphenyl ethers (PBDEs) has become a matter of concern. In this study, PBDEs were determined in farmed and wild groupers obtained from a mariculture area in Lampung to understand the contamination status and its differences between farmed and wild groupers, and to evaluate the proportion of their congeners as well as risks and benefits of consuming contaminated fish. Fourteens PBDE congeners from mono- to deca BDE were analyzed from samples stored in es-Bank using gas chromatography equipped with mass spectrometry detector (GC-MS). PBDEs were detected in all the samples of the present study, with the levels being significantly higher $(p<0.01)$ in farmed (1.1-6.2 ng/g lipid wt) than in wild groupers $(0.20-1.1 \mathrm{ng} / \mathrm{g}$ lipid wt). Analysis of fish feeds indicated that the higher level of contaminants in farmed groupers most likely came from the commercial fish feed which they consumed. The study confirms relatively high concentrations of these compounds in farmed than wild fish. However, the levels still bellow to those farmed fish reported worldwide but have similar composition pattern of congeners being BDE-47 as predominant congener. The evaluation of PBDEs concentration in groupers showed that the levels were still bellow than fish tissue guideline. Furthermore, the estimated daily intake of PBDEs was also far bellow the reference dose values (RfDs) and/or Minimum Risk Levels (MRL), indicating minimum risk caused by these pollutants to groupers as well as to Indonesian from consuming fish.
\end{abstract}

Keywords: contamination, PBDEs, farmed grouper, wild grouper, health risk.

\section{ABSTRAK}

Berkaitan dengan isu ketahanan dan keamanan pangan, evaluasi terhadap resiko dan manfaat dari produk perikanan terhadap pencemaran lingkungan dari polybrominated diphenyl ethers (PBDEs) telah menjadi perhatian. Pada penelitian ini, PBDEs dideterminasi pada ikan kerapu budidaya dan kerapu liar dari daerah Lampung untuk mengetahui status kontaminasi dan perbedaan diantara dua kelompok kerapu, mengevaluasi proporsi konjener penyusun serta risiko dan manfaat dari mengkonsumsi ikan yang terkontaminasi. Empat belas konjener PBDEs dari mono- sampai ke deka BDE dianalisis dari sampel yang tersimpan di es-BANK menggunakan kromatografi gas yang dilengkapi dengan detektor spektrometri massa (GC-MS). PBDEs terdeteksi di semua sampel kerapu, dengan konsentrasi secara signifikan lebih tinggi $(p<0,01)$ pada kerapu budidaya $(1,1-6,2 \mathrm{ng} / \mathrm{g}$ lipid wt) daripada di kerapu liar $(0,20-1,1 \mathrm{ng} / \mathrm{g}$ lipid wt). Analisis pakan ikan menunjukkan bahwa tingkat kontaminan yang lebih tinggi di kelompok kerapu budidaya ini kemungkinan berasal dari pakan ikan komersial yang mereka konsumsi. Studi ini menegaskan bahwa ikan budidaya mempunyai konsentrasi PBDEs yang lebih tinggi daripada ikan liar. Namun demikian, kadar konsentrasi PBDEs pada kerapu budidaya ini masih lebih rendah daripada yang dilaporkan pada beberapa ikan budidaya di seluruh dunia, tetapi memiliki pola komposisi konjener yang sama dimana BDE-47 merupakan konjener yang dominan. Evaluasi konsentrasi PBDEs pada kerapu memperlihatkan bahwa kadarnya masih di bawah standar rujukan untuk konsentrasi pada jaringan ikan. Selanjutnya, perkiraan asupan harian PBDEs juga masih jauh di bawah nilai rujukan dosis referensi (RfDs) dan/atau Tingkat Risiko Minimum (MRL), menunjukkan potensi dampak yang rendah pada jaringan ikan itu sendiri maupun kesehatan orang Indonesia karena mengkonsumsi kerapu.

Kata kunci: kontaminasi, PBDEs, kerapu budidaya, kerapu liar, resiko kesehatan 


\section{PENDAHULUAN}

\subsection{Latar Belakang}

Di sektor perikanan budidaya, terdapat keragaman spesies kultivar, diantaranya kerapu yang merupakan salah satu ikan komersial penting yang diminati di pasar lokal maupun internasional ${ }^{(1,2)}$. Selain penggunaan benih yang ditangkap di alam, budidaya kerapu di Indonesia umumnya dicirikan oleh hasil dari pembenihan, serta penggunaan pelet dan ikan runcah untuk pakan ${ }^{(3,4)}$. Produksi budidaya ikan ini terus meningkat dengan tingkat pertumbuhan rata-rata $13 \%$ dari 2009-2012, dimana produksi tahun 2009 mencapai 8.791 ton meningkat 13.338 ton pada tahun $2012^{(1,2)}$ dan di tahun 2013 menjadi 18.864 ton $^{(2)}$. Data terakhir menunjukkan peningkatan $300 \%$ dari 11.504 ton pada tahun 2016 menjadi 46.504 ton pada $2017^{(5)}$. Sumatra termasuk merupakan daerah penghasil utama produksi kerapu dengan total output 5.913 ton pada 2012 dan meningkat 7.336 ton pada tahun $2015^{(1,5)}$

Ikan kerapu merupakan sumber pangan yang mengandung protein dan asam lemak tidak jenuh omega-3 yang sangat bermanfaat bagi kesehatan manusia. Saat ini, selain masalah ketahanan pangan (food security), keamanan pangan (food safety) juga menjadi isu penting dalam penyediaan bahan pangan karena berhubungan dengan potensi dampak kesehatan yang dapat ditimbulkan. Karena itu, terdapat kekhawatiran tentang tingkat pencemaran lingkungan dan hubungannya dengan risiko kesehatan termasuk dari konsumsi ikan yang tercemar. Sementara itu, area budidaya ikan telah diketahui sebagai salah satu sumber pencemaran ke lingkungan sekitar ${ }^{(6)}$, termasuk memberikan paparan polutan ke dalam produk ikan budidaya ${ }^{(6,7)}$, dimana diantaranya polybrominated diphenyl ethers (PBDEs) adalah polutan yang menjadi perhatian ${ }^{(6,7)}$. Sejalan dengan hal tersebut, maka penelitian untuk menilai risiko dan manfaat konsumsi ikan karena pencemaran juga telah meningkat, termasuk dengan senyawa PBDEs ${ }^{(7,8,9)}$. Di Indonesia, belum ada penelitian yang mengukur seberapa besar kandungan bahan pencemar PBDEs di ikan budidaya dan bagaimana potensi resiko kesehatan akibat konsumsi ikan.

PBDEs merupakan salah satu senyawa dalam kelompok brominated flame retardants (BFRs) yang secara struktural mirip dengan polychlorinated biphenyls (PCBs) yang merupakan polutan organik yang persisten (Peristent Organic Pullutants - POPs), terdiri dari kemungkinan 209 konjener. Struktur kimia terdiri dari dua cincin aromatik halogen, yang tersusun dari beberapa homolog konjener yaitu mono, di, tri, tetra, penta, hexa, okta dan deka PBDE tergantung pada jumlah atom bromida yang ditambahkan ke molekul ${ }^{(10,11)}$. PBDEs yang mencemari lingkungan terutama berasal dari tiga campuran produk komersial, yaitu pentaBDE (BDE=Brominated Dipehnyl Ether), octaBDE dan decaBDE yang digunakan sebagai aditif pada berbagai produk polimer dan telah diterapkan pada furnitur, tekstil, peralatan elektronik dan bahan bangunan untuk mengurangi sifat mudah terbakar. Produk PBDE komersial yang tersedia bukanlah disusun dari satu konjener melainkan campuran beberapa konjener dengan komposisi tertentu ${ }^{(11)}$. Di Amerika Serikat, PBDE dipasarkan dengan nama dagang: DE-60F, DE-61, DE-62, dan DE-71 yang diterapkan pada campuran pentaBDE; DE-79 diterapkan pada campuran octaBDE; dan DE 83R dan Saytex 102E diterapkan pada campuran decaBDE ${ }^{(11)}$. Di Indonesia sendiri belum ada informasi yang diperoleh terkait dengan produk PBDE komersial apa yang digunakan ${ }^{(12)}$.

Sebagai bahan additive pada produk polimer, PBDEs dapat berpindah dan mencemari lingkungan selama proses produksi, penggunaan produk, disposal maupun proses daur ulang ${ }^{(10)}$. PBDEs dimasukkan sebagai salah satu daftar senyawa POPs oleh Konvensi Stockholm (Stockholm Convention) karena sifatnya yang tahan urai, mudah terakumulasi dalam jaringan tubuh organisme, dapat mudah tersebar ke berbagai lingkungan dan sangat beracun ${ }^{(13)}$.

Konsumsi bahan makanan merupakan sumber utama paparan PBDEs ke manusia, dan produk-produk perikanan seperti ikan dan kerang-kerangan merupakan penyumbang tinggi terhadap rute paparan tersebut ${ }^{(14,15)}$. Karena itu, penting sekali untuk dapat memantau kadar PBDEs pada produk bahan makanan termasuk seafood sebagai bagian dari upaya yang diamanatkan dalam Rencana Aksi Nasional Indonesia dari Konvensi Stockholm untuk senyawa POPs ${ }^{(12)}$ dan dapat menjadi dasar dalam penentuan kebijakan terkait penguatan keamanan pangan. Informasi saat ini menunjukkan bahwa, PBDEs telah terdeteksi di berbagai kompartemen di Indonesia, seperti $\operatorname{tanah}^{(16,17)}$, sedimen ${ }^{(18,19)}$; ikan, udang, kepiting dan kerang dari Teluk Jakarta ${ }^{(20)}$, serta air susu ibu dari berbagai lokasi ${ }^{(21)}$. Namun demikian belum ada data terkait paparan PBDEs di ikan budidaya dan perbandingannya dengan ikan tangkapan dari alam (ikan liar).

\subsection{Tujuan Penelitian}

Penelitian ini bertujuan untuk melakukan retrospektif pengukuran kehadiran 14 (empat belas) konjener dari senyawa PBDEs pada ikan kerapu hasil budidaya, kerapu hasil tangkapan dan berbagai jenis pakan ikan. Konsentrasi PBDEs yang diperoleh digunakan untuk 
mengevaluasi derajat nilai kandungan pada ikan, perbandingan konsentrasi pada ikan budidaya dengan ikan tangkapan, perbandingannya dengan referensi di berbagai belahan dunia, dan mengetahui pola dominasi akumulasi konjener, serta resikonya terhadap kesehatan ikan dan manusia melalui paparan senyawa ini dari konsumsi ikan.

\section{BAHAN DAN METODE}

\subsection{Sampel dan Sampling}

Sampel yang digunakan berupa ikan kerapu budidaya dan kerapu hasil tangkapan di alam (liar) yang dikoleksi pada 23 Juli 2004 (Tabel 1). Pengambilan sampel kerapu budidaya dilakukan di Balai Besar Budidaya Laut Lampung (BBBL Lampung), sedangkan sampel kerapu liar diperoleh dari tangkapan di perairan sekitarnya (Teluk Lampung) oleh nelayan setempat. Ikan kerapu budidaya dewasa yang siap panen dipilih dalam penelitian ini.

Tabel 1. Sampel kerapu yang digunakan $(B D=$ Budidaya, $\mathrm{L}=\mathrm{Liar}$ ) dalam penelitian ini.

\begin{tabular}{cccccc}
\hline NO & $\begin{array}{c}\text { Sampel } \\
\text { ID }\end{array}$ & Nama Umum & $\begin{array}{c}\text { Berat } \\
\text { (gr) }\end{array}$ & $\begin{array}{c}\text { Panjang } \\
(\mathbf{c m})\end{array}$ & Waktu \\
\hline $\mathbf{1}$ & BD-1 & Kerapu macan & 1124 & 37 & $23 / 7 / 2004$ \\
\hline $\mathbf{2}$ & BD-2 & Kerapu macan & 801 & 35 & $23 / 7 / 2004$ \\
\hline $\mathbf{3}$ & BD-3 & Kerapu macan & 632 & 31 & $23 / 7 / 2004$ \\
\hline $\mathbf{4}$ & BD-4 & Kerapu macan & 570 & 28 & $23 / 7 / 2004$ \\
\hline $\mathbf{5}$ & BD-5 & Kerapu macan & 563 & 28 & $23 / 7 / 2004$ \\
\hline $\mathbf{6}$ & BD-6 & Kerapu macan & 954 & 37 & $23 / 7 / 2004$ \\
\hline $\mathbf{7}$ & BD-7 & Kerapu macan & 1497 & 46 & $23 / 7 / 2004$ \\
\hline $\mathbf{8}$ & BD-8 & Kerapu macan & 589 & 28 & $23 / 7 / 2004$ \\
\hline $\mathbf{9}$ & BD-9 & Kerapu macan & 601 & 31 & $23 / 7 / 2004$ \\
\hline $\mathbf{1 0}$ & L-1 & Kerapu Muara & 820 & 40 & $23 / 7 / 2004$ \\
\hline $\mathbf{1 1}$ & L-2 & Kerapu Muara & 522 & 33 & $23 / 7 / 2004$ \\
\hline $\mathbf{1 2}$ & L-3 & Kerapu Muara & 640 & 36 & $23 / 7 / 2004$ \\
\hline $\mathbf{1 3}$ & L-4 & Kerapu Lumpur & 1194 & 43 & $23 / 7 / 2004$ \\
\hline $\mathbf{1 4}$ & L-5 & Kerapu Lumpur & 1341 & 45 & $23 / 7 / 2004$ \\
\hline $\mathbf{1 5}$ & L-6 & Kerapu Lumpur & 761 & 38 & $23 / 7 / 2004$ \\
\hline
\end{tabular}

Bersamaan dengan itu juga diambil berbagai macam jenis pakan ikan kerapu budidaya, yaitu pellet, minyak suplemen dan ikan runcah (Tabel 2). Jenis kerapu budidaya $(n=9)$ pada penelitian ini yaitu Kerapu Macan (Epinephelus fuscoguttatus), sedangkan kerapu liar $(n=6)$ yang diperoleh meliputi Kerapu Muara (Epinephelus coioides) ( $n=3)$ dan Kerapu Lumpur (Epinephelus malabaricus) ( $n=3$ ). Di laboratorium, sampel ikan diukur secara biometrik, dibedah dan diambil sampel daging yang terpisah dari kulitnya (fillet). Sampel fillet disimpan dalam kotak es, dikirim ke Jepang dan kemudian disimpan pada suhu $-20^{\circ} \mathrm{C}$ di es-BANK (CMES, Universitas Ehime, Jepang) sampai analisis kimia $\left.{ }^{(22)}\right)$. Proses pengiriman dan penyimpanan spesimen sampel ke es-BANK merupakan bagian dari kerjasama antara Badan Pengkajian dan Penerapan Teknologi (BPPT) dengan CMES. Spesimen yang tersimpan dalam es-BANK dapat diakses melalui http://esbankehime.com/dnn/.

Tabel 2. Pakan dan suplemen ikan untuk kerapu budidaya dalam penelitian ini.

\begin{tabular}{cccccc}
\hline No & Kode & Merek & $\begin{array}{c}\text { Asal } \\
\text { Produk }\end{array}$ & $\begin{array}{c}\text { Bentuk } \\
\text { Pakan }\end{array}$ & Waktu \\
\hline $\mathbf{1}$ & LL-2 & C & Jepang & Pelet & $7 / 23 / 2004$ \\
\hline $\mathbf{2}$ & LL-5 & C & Jepang & Pelet & $7 / 23 / 2004$ \\
\hline $\mathbf{3}$ & CF-12 & D & Indonesia & Pelet & $7 / 23 / 2004$ \\
\hline $\mathbf{4}$ & SO-1 & - & Indonesia & Minyak & $7 / 23 / 2004$ \\
\hline $\mathbf{5}$ & TF-1 & - & Indonesia & Runcah & $7 / 23 / 2004$ \\
\hline
\end{tabular}

\subsection{Target Konjener PBDEs}

Dalam penelitian ini difokuskan pada 14 konjener PBDEs, mulai dari mono- sampai deka$\mathrm{BDE}$. Keempat belas target konjener itu dengan masing-masing Nomor IUPAC, yaitu \#3- (mono BDE), 15- (Di BDE), 28- (Tri BDE), 47- (Tetra BDE), 99- (Penta BDE), 100- (Penta BDE), 153(Hexa BDE), 154- (Hexa BDE), 183- (Hepta BDE), 196- (Octa BDE), 197- (Octa BDE), 206(Nona BDE), 207- (Nona BDE), dan 209- (Deca $\mathrm{BDE})$, dimana konjener-konjener ini mencerminkan konjener yang terdapat pada formulasi produk komersial $^{(11)}$ dan biasa terdeteksi di lingkungan ${ }^{(10)}$.

\subsection{Analisis PBDEs}

Prosedur analisis PBDEs dilakukan berdasarkan metodologi yang telah dioptimalisasi untuk sampel ikan di Laboratorium Kimia Lingkungan dan Toksikologi, CMES ${ }^{(23)}$. Secara ringkas, sekitar 20-30 g berat basah dari sampel fillet dan pakan ikan dihomogenisasi dengan natrium sulfat teraktivasi. Sebelum diekstrak lebih lanjut, sampel ditambahkan label karbon PBDEs $\left({ }^{13} \mathrm{C}_{12}\right.$-BDEs) meliputi ${ }^{13} \mathrm{C}_{12}$-BDE-3, -15, -28, -47, $99,-153,-154,-183,-197,-207$ and -209 sebanyak $5 \mathrm{ng}$. Bersamaan dengan ini juga ditambahkan label karbon PCBs $\left({ }^{13} \mathrm{C}_{12}\right.$-PCBs sebanyak $5 \mathrm{ng}$ ) dan ${ }^{13} \mathrm{C}-\mathrm{HBCD}\left(\alpha-, \beta-\right.$ dan $\gamma^{-}$ ${ }^{13} \mathrm{C}_{12}$-HBCD sebanyak $10 \mathrm{ng}$ ) untuk analisis senyawa lain di luar target tulisan ini, yaitu PCBs dan hexabromocyclo-dodecanes (HBCDs). Label karbon $\left({ }^{13} \mathrm{C}_{12}\right)$ ini berfungsi sebagai internal standar untuk rekoveri (labeled recovery internal standard - LRIS) yaitu untuk pengukuran efisiensi ekstraksi dan mengkoreksi konsentrasi senyawa yang hilang selama proses analisis sebelum kuantifikasi menggunakan alat.

Sampel yang telah ditambahkan LRIS diekstraksi dengan $50 \%$ aseton /heksana (v/v) menggunakan peralatan accelerated solvent extractor (SE-100, Mitsubishi) selama 30 menit pada laju alir $10 \mathrm{~mL}$ per menit. Sebanyak $20 \%$ ekstrak sampel diambil terpisah untuk digunakan 
dalam penentuan kandungan lipid (lemak) secara gravimetri dan nilainya digunakan untuk keperluan konversi konsentrasi PBDEs dalam berat basah $(\mathrm{ww}=$ wet weight) dari sampel. Sisa $80 \%$ ekstrak sampel kemudian dipurifikasi melalui kolom kromatografi permeasi gel (Gel Permeation Chromatography - GPC; Bio-Beads S-X3, Laboratorium Bio-Rad, CA, diameter $2 \mathrm{~cm}$ dan panjang kolom $5 \mathrm{~cm}$ ) dengan elutan $50 \%$ heksana/diklorometana (1:1).

Larutan fraksi GPC yang mengandung target organohalogen termasuk PBDEs dikonsentrasikan sampai volume $1 \mathrm{~mL}$ dan kemudian di purifikasi kembali serta fraksinasi lebih lanjut melalui kolom kromatografi mengandung $4 \mathrm{~g}$ gel silika aktif (Wakogel DX, Wako Pure Chemical Industries Ltd., Japan) dengan elutan diklorometana $5 \%$ dalam heksana. Fraksi pertama yang mengandung PBDEs dan PCBs dielusi dengan $80 \mathrm{ml}$ diklorometana $5 \%$ dalam heksana $(\mathrm{v} / \mathrm{v})$ dan fraksi kedua yang mengandung HBCDs dielusi dengan $100 \mathrm{ml}$ diklorometana $20 \%$ dalam heksana (v/v). Fraksi pertama yang mengandung PBDEs dan PCBs dikonsentrasikan sampai volume $5 \mathrm{ml}$ sebagai larutan akhir dan kemudian ditambahkan larutan standard internal berlabel $\left({ }^{13} \mathrm{C}_{12}\right.$-label BDE-139) berfungsi untuk mengkoreksi faktor kinerja instrumen dan sampel matriks (Labeled Instrument Performance and Matrix Internal Standard - LIPMIS), sebelum dianalisis untuk kuantifikasi menggunakan kromatografi gas (Gas Chromatography - GC) dengan detektor spektrometri massa (Mass Spectrometry Detector - MSD) (GC-MSD). LIPMIS akan menghitung faktor fluktuasi instrumental dari spektrometer massa di antara injeksi sampel yang dianalisis, serta penekanan ionisasi atau efek peningkatan yang timbul dari matriks sampel $\left.{ }^{(24)}\right)$.

Kuantifikasi dilakukan dengan menggunakan GC (Agilent 6890N) yang dilengkapi dengan MSD (Agilent 5973N) untuk PCBs dan mono-heptaBDE (BDE-3, -15, -28, -47, -99, -100, -153, - 154, dan -183), dan GC (Agilent 6890N) ditambah dengan MSD (JEOL GCMate II) untuk octasampai deka-BDE (BDE-196, -197, -206, -207, dan -209), menggunakan ionisasi elektron dengan mode pemantauan ion secara selektif (electron ionization with selective ion monitoring : EI-SIM). Kolom GC adalah DB-1 fused silica capillary ( $\mathrm{J} \& \mathrm{~W}$ Scientific Inc.) dengan $30 \mathrm{~m} \times$ $0,25 \mathrm{~mm}$ i.d. $\times 0.25 \mu \mathrm{m}$ ketebalan film untuk mono-hepta-BDE. Sedangkan untuk octasampai-deca-BDEs, menggunakan kolom VF1 MS capillary column dengan $15 \mathrm{~m} \times 0,25 \mathrm{~mm}$ i.d. $x \quad 0,1 \mu \mathrm{m}$ ketebalan film. Semua target konjener diukur menggunakan metode pengenceran isotop (isotop dillution) ke masingmasing konjener berlabel ${ }^{13} \mathrm{C}_{12} \quad\left({ }^{13} \mathrm{C}_{12}\right.$-BDE). Rekoveri dari ${ }^{13} \mathrm{C}_{12}$-BDE berkisar antara $56 \%$ dan
$110 \%$ tergantung pada konjener. Konsentrasi individu konjener dan isomer dijumlahkan untuk mendapatkan konsentrasi total PBDE (PBDEs) yang dinyatakan sebagai $\mathrm{ng} / \mathrm{g}$ berat lemak (lipid), kecuali ditentukan lain misalnya dalam berat basah ( $\mathrm{ng} / \mathrm{g}$ berat basah).

\subsection{Jaminan Mutu dan Kontrol Kualitas Data}

Prosedural blank selalu dilakukan bersamaan dengan analisis tujuh sampel di setiap batch bertujuan untuk mengevaluasi interferensi dan kontaminasi, baik dari pelarut yang digunakan maupun gelas wadah. Konsentrasi dari sampel blank digunakan untuk koreksi rekoveri standar internal. Tergantung pada konjener, kisaran rekoveri PBDEs pada sampel blank adalah $74-110 \%$. Nilai pengulangan yang diperoleh dari tiga ulangan dijaga pada koefisien varians (CV) kurang dari $20 \%$. Konsentrasi di bawah batas deteksi dinyatakan sebagai nilai nol (ND = tidak terdeteksi).

Seluruh prosedur analisis PBDEs yang digunakan untuk sampel ikan ini telah diuji dan dibandingkan dengan hasil kalibrasi prosedur analisis yang diselenggarakan oleh National Institute for Environmental Studies (NIES), Jepang menggunakan sampel lemak mamalia laut sebagai material referensi standard (Standard Reference Material - SRM), termasuk juga diikutkan pada uji perbandingan antar laboratorium yang diselenggarakan oleh the National Institute of Standards and Technology (Gaithersburg, MD) dan the Marine Mammal Health and Stranding Response Program dari National Marine Fisheries Service-NOAA (Silver Spring, MD). Dalam hal ini, SRM 1945 dianalisis untuk konjener PBDE tertentu. Data dari prosedur analisis PBDEs yang digunakan untuk sampel ikan ini sesuai dengan hasil dari Material Referensi Standard ${ }^{(25)}$. Selain jaminan kualitas mutu analisis di atas, penggunaan standar internal juga diterapkan untuk menghindari efek sampel matriks dalam ekstrak sampel serta kinerja peralatan oleh pergantian injeksi masingmasing sampel.

\subsection{Analisis Data}

\subsubsection{Uji Statistika}

Analisis statistik non-parametrik dilakukan dengan Software IBM SPSS Version $24^{(26)}$ ). Perbedaan antara dua kelompok sampel independen (kerapu budidaya dan kerapu liar) diuji dengan Mann - Whitney U Test, dan untuk lebih dari dua kelompok sampel independen diuji dengan Kruskal Wallis Test (kelompok kerapu budidaya, kerapu tangkapan dan pakan kerapu). Hasilnya ditampilkan ulang sebagai nilai rerata dan rentang konsentrasi polutan. Sedangkan uji korelasi peringkat Spearman (Spearman ranks 
correlation) digunakan untuk menguji signifikansi korelasi antar parameter. Nilai probabilitas kurang dari $0,05(p<0,05)$ dianggap signifikan secara statistik.

\subsubsection{Karakterisasi Resiko}

Karakterisasi resiko ditujukan baik untuk resiko kadar PBDEs terhadap ikan itu sendiri maupun paparannya terhadap orang Indonesia melalui perbandingannya dengan standard rujukan (guideline). Nilai baku mutu dari berbagai referensi yang ada digunakan sebagai rujukan, seperti the Federal Fish Tissue Guidelines (FFTGs) dari the Canadian Federal Environmental Quality Guidelines ${ }^{(27)}$ untuk standar rujukan konsentrasi PBDEs pada ikan, serta US-EPA ${ }^{(28)}$ dan ATSDR $^{(29)}$ untuk standar rujukan nilai dosis referensi (Reference Dose Values - RfDs) dan level resiko minimum (Minimum Risk Level - MRL) dari estimasi paparan PBDEs melalui konsumsi ikan.

Lebih lanjut, kajian paparan dilakukan dengan memperkirakan asupan harian (Daily Intake - DI) dari 14 konjener PBDEs melalui konsumsi ikan (kerapu) oleh populasi di Indonesia menggunakan metode deterministik, yang menggabungkan data konsumsi (ikan) dan konsentrasi (PBDEs di ikan kerapu). Paparan PBDEs harian (DI) didekati melalui konsentrasi PBDEs di ikan dalam berat basah (ng/g berat basah) dan dikalikan dengan konsumsi ikan ratarata per hari per kapita di Indonesia. Konsumsi makan ikan rata-rata per hari per kapita di Indonesia menggunakan data resmi terakhir pada tahun 2016 sebesar 43,88 kg/kapita/tahun atau 120,22 g/kapita/hari yang diperoleh dari Kementerian Kelautan dan Perikanan ${ }^{(30)}$. Nilai DI dari PBDEs kemudian dibandingkan dengan nilai dosis referensi dari literatur, seperti US-EPA ${ }^{(28)}$ untuk RfDs dan ATSDR ${ }^{(29)}$ untuk MRL. Perbandingan antara DI dan RfDs merupakan nilai resiko (Hazard Quotion $=\mathrm{HQ}$ ) dari PBDEs tersebut, dimana $\mathrm{HQ}>1$ menunjukkan kemungkinan adanya resiko, sedangkan $\mathrm{HQ}<1$ menunjukkan tidak ada/minimal resiko.

\section{HASIL DAN PEMBAHASAN}

\subsection{Konsentrasi}

Dari 14 konjener PBDEs yang di analisis, hanya 7 konjener yang terdeteksi, yaitu BDE-28, 47, 49, 99, 100, 153 dan 154 (Tabel 3), sedangkan BDE-3, 183, 196, 197, 206, 207 dan 209 tidak terdeteksi. Sementara itu, konsentrasi total dari PBDE konjener yang terdeteksi pada jaringan tubuh ikan kerapu budidaya dari Lampung berkisar antara 1,1 ng/g lipid wt - 6,2 $\mathrm{ng} / \mathrm{g}$ lipid wt. atau $0,10(0,06-0,14) \mathrm{ng} / \mathrm{g}$ berat basah. Sepanjang pengetahuan, hasil ini merupakan studi pertama kali terdeteksinya
PBDEs pada ikan budidaya dari Indonesia. Namun demikian, konsentrasi ini masih berada pada rentang kisaran PBDEs yang terdeteksi pada biota dari beberapa lokasi di Indonesia ${ }^{(19,20,21)}$, seperti pada ikan dari kolam kontrol lindi TPA Benowo Surabaya berkisar 6,6$11 \mathrm{ng} / \mathrm{g}$ lipid wt. ${ }^{(19)}$; ikan, udang, kepiting dan kerang dari Teluk Jakarta masing-masing berkisar antara 1,6 ng/g lipid wt. - $57 \mathrm{ng} / \mathrm{g}$ lipid wt., 1,6 ng/g lipid wt., $20 \mathrm{ng} / \mathrm{g}$ lipid wt., dan $11 \pm 1,4 \mathrm{ng} / \mathrm{g}$ lipid wt. ${ }^{(20)}$.

Tabel 3. Konsentrasi PBDEs yang terdeteksi pada ikan kerapu budidaya, kerapu liar dan pakan ikan dari Lampung.

\begin{tabular}{|c|c|c|c|c|c|c|c|c|c|c|}
\hline \multirow{2}{*}{ ID } & \multirow{2}{*}{$\begin{array}{l}\text { Fat } \\
(\%)\end{array}$} & \multicolumn{8}{|c|}{ PBDE Konjener } & \multirow{2}{*}{$\begin{array}{l}\text { Total } \\
\text { BDEs }\end{array}$} \\
\hline & & -15 & -28 & -47 & -99 & -100 & -153 & -154 & -183 & \\
\hline BD-1 & 2,1 & 0,05 & 0,06 & 1,4 & 0,64 & 0,94 & 0,53 & 0,85 & $<0,01$ & 4,5 \\
\hline BD-2 & 3,2 & $<0,01$ & 0,04 & 1,2 & 0,41 & 0,62 & 0,35 & 0,73 & $<0,01$ & 3,4 \\
\hline BD-3 & 2,9 & 0,02 & 0,03 & 1,2 & 0,54 & 0,87 & 0,41 & 1,0 & $<0,01$ & 4,0 \\
\hline BD-4 & 2,3 & 0,02 & 0,09 & 2,4 & 0,75 & 1,2 & 0,53 & 1,2 & $<0,01$ & 6,2 \\
\hline BD-5 & 2,0 & 0,02 & 0,05 & 1,6 & 0,82 & 1,1 & 0,58 & 1,2 & $<0,01$ & 5,4 \\
\hline BD-6 & 3,3 & 0,03 & 0,06 & 1,1 & 0,49 & 0,64 & 0,39 & 0,77 & $<0,01$ & 3,5 \\
\hline BD-7 & 2,5 & 0,03 & 0,11 & 1,0 & 0,27 & 0,43 & 0,24 & 0,47 & $<0,01$ & 2,6 \\
\hline BD-8 & 3,4 & 0,02 & 0,08 & 1,1 & 0,50 & 0,63 & 0,39 & 0,74 & $<0,01$ & 3,5 \\
\hline BD-9 & 1,5 & 0,05 & 0,16 & 1,8 & 0,49 & 0,77 & 0,42 & 0,82 & $<0,01$ & 4,6 \\
\hline L-1 & 0,40 & $<0,01$ & 0,08 & 0,4 & 0,44 & 0,22 & $<0,01$ & $<0,01$ & $<0,01$ & 1,1 \\
\hline L-2 & 0.71 & $<0,01$ & 0,06 & 0,16 & $<0,01$ & $<0,01$ & $<0,01$ & $<0,01$ & $<0,01$ & 0,2 \\
\hline L-3 & 0.57 & $<0,01$ & 0,04 & 0,62 & 0,22 & 0,34 & $<0,01$ & $<0,01$ & $<0,01$ & 1,6 \\
\hline L-4 & 0.51 & $<0,01$ & 0,09 & 0,47 & 0,21 & 0,15 & $<0,01$ & $<0,01$ & $<0,01$ & 0,9 \\
\hline L-5 & 0.51 & $<0,01$ & 0,05 & 0,32 & 0,27 & 0,14 & $<0,01$ & $<0,01$ & $<0,01$ & 0,8 \\
\hline L-6 & 0.21 & $<0,01$ & 0,11 & 0,67 & $<0,01$ & $<0,01$ & $<0,01$ & $<0,01$ & $<0,01$ & 0,8 \\
\hline LL-2 & 10 & $<0,01$ & 0,12 & 1,1 & 0,32 & 0,24 & 0,11 & 0,19 & $<0,01$ & 2,1 \\
\hline LL-5 & 9.2 & $<0,01$ & 0,33 & 4,6 & 0,64 & 1,1 & 0,20 & 0,44 & 0,02 & 7,3 \\
\hline CF-12 & 12 & $<0,01$ & 0,04 & 0,64 & 0,23 & 0,15 & 0,04 & 0,10 & 0,02 & 1,2 \\
\hline TF-1 & 1.3 & $<0,01$ & $<0,01$ & 1,1 & 0,15 & 0,36 & 0,21 & 0,50 & $<0,01$ & 2,4 \\
\hline so & 86 & $<0,01$ & 0,02 & 0,08 & 0,02 & 0,04 & 0,01 & 0,01 & 0,02 & 0,2 \\
\hline
\end{tabular}

BDE-209 tidak terdeteksi (tidak ditampilkan dalam Tabel)

Konsentrasi total PBDEs pada kerapu hasil budidaya ini secara signifikan lebih tinggi dibandingkan dengan kerapu liar $(p<0,01)$ (Gambar 1, Tabel 3). Rata-rata total PBDEs pada kerapu budidaya yaitu $4,2 \mathrm{ng} / \mathrm{g}$ lipid wt, sedangkan pada kerapu liar yaitu $0,90 \mathrm{ng} / \mathrm{g}$ lipid wt. Hasil perbandingan kerapu budidaya dengan kerapu liar dari Lampung ini konsisten dengan perbandingan PBDEs pada ikan salmon (budidaya dan liar) dari berbagai lokasi di dunia, seperti pantai Pasifik dari Amerika Utara ${ }^{(8)}$, Eropa, Amerika Utara dan Amerika Selatan ${ }^{(9)}$; Kanada $^{(31)}$, serta Chili ${ }^{(32)}$. 


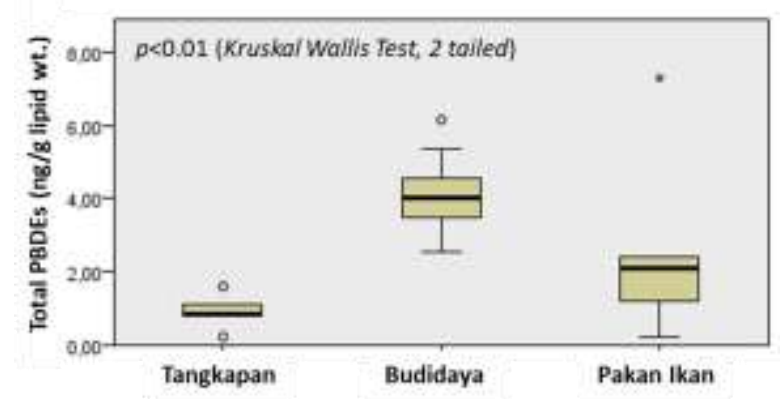

Gambar 1. Konsentrasi PBDEs pada kerapu dan pakan ikan.

Dalam penelitian ini, perbedaan yang signifikan antara konsentrasi kontaminan pada ikan budidaya dan ikan liar kemungkinan besar merupakan fungsi dari pakan. Ikan kerapu budidaya diberi pakan berupa pellet dan minyak ikan dengan kandungan lemak yang tinggi. Pada penelitian ini, terdapat perbedaan yang signifikan antara kandungan lemak pada ikan budidaya dan ikan liar $(p<0,05)$, yang menunjukkan pengaruh dari pakan/suplemen ikan dimana kerapu budidaya mempunyai kandungan lemak yang tinggi (Tabel 3). Sementara itu, konsentrasi PBDEs pada pakan ikan juga secara signifikan lebih tinggi dari kerapu liar (Gambar 1), menunjukkan kemungkinan fungsi pakan pada tingginya PBDEs di ikan kerapu budidaya.

Meskipun demikian, studi perbandingan kandungan PBDEs pada ikan budidaya dibandingkan ikan liar juga memperlihatkan hasil yang tidak selalu sama. Staskal dkk. ${ }^{(33)}$, misalnya melaporkan bahwa kandungan dari 43 (empat puluh tiga) konjener PBDEs lebih tinggi pada fillet lele hasil tangkapan dari Mississippi daripada fillet ikan lele budidaya yang diambil dari daerah yang sama. Staskal dkk. ${ }^{(33)}$ menyampaikan bahwa hal ini kemungkinan adanya sumber pencemaran pada wilayah sungai pada tingginya PBDEs di ikan lele liar. Sementara, Shaw dkk. ${ }^{(34)}$ melaporkan tidak ada perbedaan dalam kandungan dari 9 (sembilan) konjener PBDEs yang dianalisis pada salmon budidaya dan salmon hasil tangkapan liar, kemungkinan karena jenis salmon liar yang digunakan mempunyai trofik level yang lebih tinggi dibanding jenis salmon budidaya. Karena itu, perbedaan dengan studi kerapu dari Lampung dan semua hasil penelitian tersebut di atas mungkin disebabkan karena variabilitas jenis ikan dan sumber PBDEs di lingkungan lokal dan sumber pakan ikan budidaya sebagaimana juga yang disampaikan oleh Klasing dan Brodber ${ }^{(35)}$. Selain itu mungkin juga disebabkan oleh perbedaan jumlah target konjener yang dianalisis oleh masing-masing studi.

Sepanjang penelusuran referensi, saat ini belum ada kajian perbandingan konsentrasi PBDEs pada ikan budidaya dan tangkapan untuk jenis kerapu dari lokasi lain di Indonesia dan negara lain, kecuali untuk jenis biota lain, seperti salmon $(7,9,32,34,38)$, ikan lele ${ }^{(33)}$ dan kerang ${ }^{(36)}$. Karena itu, pada peneltian ini akan dibandingkan dengan hasil-hasil referensi tersebut. Meskipun terdapat ketidak konsistenan dari beberapa referensi, tingginya kandungan PBDEs di kerapu budidaya dibanding dengan kerapu liar pada penelitian ini adalah sejalan dengan hasil penelitian pada ikan salmon dari berbagai tempat di dunia seperti Skotlandia, Norwegia, Kanada dan Chili ${ }^{(9)}$.

Dalam penelitian ini (Tabel 4), rata-rata konsentrasi PBDEs pada kerapu budidaya dari Lampung $(4,2 \mathrm{ng} / \mathrm{g}$ lipid wt atau $0,10 \mathrm{ng} / \mathrm{g}$ berat basah) lebih rendah dari yang ditemukan pada salmon budidaya dari Chili $(15,9 \mathrm{ng} / \mathrm{g}$ lipid $\mathrm{wt})$, Belgia (19,6 ng/g lipid wt), Norwegia $(20,7 \mathrm{ng} / \mathrm{g}$ lipid wt ${ }^{(37)}$, Skotlandia $\left(53,6 \mathrm{ng} / \mathrm{g}\right.$ lipid wt.) ${ }^{(7)}$, dan beberapa lokasi lain di Eropa dan Amerika (>1.0 - sekitar $4.0 \mathrm{ng} / \mathrm{g}$ berat basah) ${ }^{(9)}$; lele budidaya dari Mississippi berkisar 0,30-23,3 ng/g berat basah $^{(33)}$ dan kerang dari Mediterranean berkisar $0,20-6,9 \mathrm{ng} / \mathrm{g}$ berat kering ${ }^{(36)}$.

Tabel 4. Perbandingan PBDEs pada kerapu (Iw= berat lemak; $w w=$ berat basah) dengan berbagai ikan budidaya dari negara lain.

\begin{tabular}{|c|c|c|c|c|c|c|}
\hline \multirow{2}{*}{ Negara } & \multirow{2}{*}{ Sampel } & \multirow{2}{*}{ Tahun } & \multirow{2}{*}{$n$} & \multicolumn{2}{|c|}{ Konsentrasi } & \multirow{2}{*}{ Ref. } \\
\hline & & & & ng/g Iw & ng/g ww & \\
\hline Skotlandia & Salmon & 2001 & 8 & $\begin{array}{c}53,6 \\
(1,1-85,2)\end{array}$ & $\begin{array}{c}0,54 \\
(0,013-1,02)\end{array}$ & (7) \\
\hline Belgia & Salmon & 2001 & 5 & $\begin{array}{c}19,6 \\
(3,1-52,1)\end{array}$ & $\begin{array}{c}0,17 \\
(0,10-0,56) \\
\end{array}$ & (7) \\
\hline Skotlandia & Salmon & 2002 & 30 & tt & $\pm 4,0^{*}$ & $(9)^{\star *}$ \\
\hline Kanada & Salmon & 2002 & 42 & $\mathrm{tt}$ & $\pm 3,0^{*}$ & (9) \\
\hline Faroe & Salmon & 2002 & 24 & $\mathrm{tt}$ & $\pm 3,0^{*}$ & (9) \\
\hline Maine & Salmon & 2002 & 6 & $\mathrm{tt}$ & $\pm 2,5^{*}$ & (9) \\
\hline Norwegia & Salmon & 2002 & 12 & $\mathrm{tt}$ & $\pm 2,5^{*}$ & (9) \\
\hline Washington & Salmon & 2002 & 9 & $\mathrm{tt}$ & $>1,0^{*}$ & (9) \\
\hline Chili & Salmon & 2002 & 30 & $\mathrm{tt}$ & $>1,0^{*}$ & (9) \\
\hline Maine, USA & Salmon & 2003 & 6 & 7,3 & 0,95 & (34) \\
\hline Kanada & Salmon & 2003 & 9 & 6,3 & 0,85 & (34) \\
\hline Norwegia & Salmon & 2004 & 3 & 5,7 & 1,0 & (34) \\
\hline Norwegia & Salmon & 2003 & 10 & $\begin{array}{c}20,7 \\
(12-29,4)\end{array}$ & $\begin{array}{c}2,75 \\
(1,6-3,9)\end{array}$ & (38) \\
\hline Chili & Salmon & 2004 & 14 & $\begin{array}{c}15,9 \\
(11,5-24)\end{array}$ & $\begin{array}{c}1,46 \\
(0,90-2,0) \\
\end{array}$ & (32) \\
\hline Mississippi & Lele & 2006 & 23 & $\begin{array}{c}6,2 \\
(3,6-9,5)\end{array}$ & $\begin{array}{c}0,50 \\
(0,30-0,80)\end{array}$ & (33) \\
\hline Mediterania & Kerang & 2009 & 40 & tt & $0,20-6,9^{\star *}$ & (38) \\
\hline Indonesia & Kerapu & 2004 & 9 & $\begin{array}{c}4,2 \\
(2,6-6,2)\end{array}$ & $\begin{array}{c}0,10 \\
(0,06-0,14)\end{array}$ & Studi ini \\
\hline
\end{tabular}

Perbedaan konsentrasi pada ikan kerapu budidaya dari Indonesia dan salmon dari berbagai negara, selain mungkin disebabkan oleh perbedaan faktor biologis seperti perbedaan spesies dan tropik level juga mungkin disebabkan oleh faktor perbedaan paparan dari pakan ikan. Seperti diketahui pakan pellet yang digunakan untuk Kerapu budidaya dari Indonesia 
mempunyai konsentrasi PBDEs (1,2-4,7 ng/g lipid wt) yang lebih rendah dari pakan ikan untuk salmon dari berbagai negara maju $(1,3-33,24$ $\mathrm{ng} / \mathrm{g}$ lipid wt. ${ }^{(9)}$. Dalam hal ini, asimilasi kontaminan organik dari rute paparan lain, seperti dari air ke ikan dapat diabaikan karena merupakan rute akumulasi yang sangat kecil ${ }^{(40)}$, daripada melalui makanan atau rantai makanan. Karena itu, rendahnya konsentrasi PBDEs pada pakan ikan untuk ikan kerapu budidaya dari Indonesia juga dapat mencerminkan derajat konsentrasi kontaminan PBDEs yang lebih rendah di kerapu budidaya dari Indonesia di bandingkan dengan salmon budidaya dari Atlantik Utara Eropa dan Amerika Utara.

Selain itu mungkin juga disebabkan karena perbedaan standard komposisi nutrisi pada pakan, terutama kandungan lemak yang dapat mempengaruhi kadar PBDEs. Kandungan lemak pada pakan pellet kerapu dari Indonesia 9,6-12\% (1,2\% untuk pakan runcah) jauh lebih rendah dari pakan pellet salmon dari negara maju sebesar $28,25-38,84 \%$. Standar rujukan formulasi pakan salmon biasanya mengandung $45-54 \%$ protein dan $16-24 \%$ lemak pada saat stadium media air tawar (awal pertumbuhan) dan $45-48 \%$ protein dan 30-40\% lemak pada saat stadium media air laut (masa dewasa) ${ }^{(39)}$. Sementara itu, pakan ikan kerapu biasanya lebih banyak menggunakan ikan runcah (trash fish) yang diperoleh dari lingkungan sekitar daripada pakan pellet dengan formulasi yang dibutuhkan $47-48 \%$ protein dan $9-12 \%$ lemak $^{(40)}$.

\subsection{Komposisi Konjener PBDEs}

Kajian komposisi konjener PBDEs dapat digunakan untuk menggambarkan berbagai proses akumulasi PBDEs, seperti selektif bioakumulasi (asimilasi), potensi adanya biodegradasi, maupun untuk merunut sumber asal produk PBDEs yang digunakan (environmental forensic). Gambar 2 menunjukkan komposisi masing-masing konjener pada seluruh sampel yang dianalisis (kerapu budidaya, kerapu liar, pakan pellet dan runcah) dan dibandingkan dengan komposisi konjener di produk komersial PBDEs yang diperoleh dari literatur ${ }^{(11)}$.

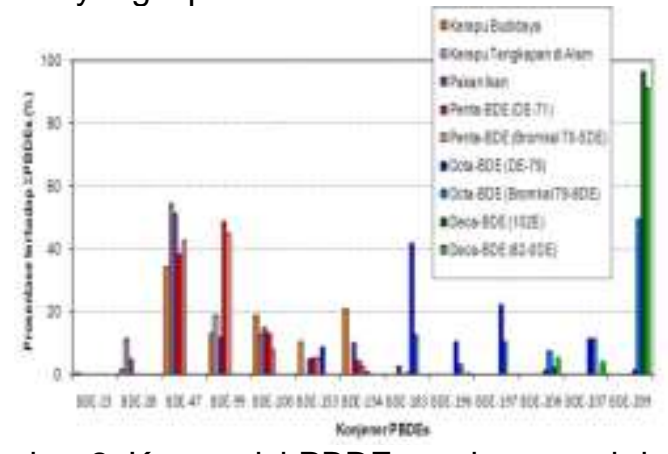

Gambar 2. Komposisi PBDEs pada sampel dan formulasi produk komersial PBDEs.
Secara umum dari konjener yang terdeteksi (BDE-28, 47, 49, 99, 100, 153 dan 154), BDE-47 adalah konjener yang paling dominan di kerapu budidaya disusul BDE-154, 100, 99 dan 153 (Gambar 2), sama dengan profil yang terdapat pada sampel pakan ikan, menunjukkan efektif akumulasi PBDEs dari pakan ke kerapu budidaya. Komposisi PBDE konjener pada ikan kerapu ini sesuai dengan profil PBDEs pada ikan salmon budidaya dan berbagai studi lingkungan khususnya di biota ${ }^{(41,7)}$. BDE 47 adalah konjener yang cepat berasimilasi pada jaringan tubuh biota dibandingkan dengan konjener PBDEs lainnya sehingga umum ditemukan dominan pada organisme $^{(42)}$. Selain itu dalam studi tropodinamika PBDEs di biota dari Teluk Jakarta, BDE-47 juga menunjukkan potensi biomagnifikasi terbesar di banding konjener lainnya ${ }^{(20)}$.

Selain selektif bioakumulasi, tingginya proporsi BDE-47 juga dapat disebabkan karena tambahan komposisi dari hasil biodegradasi konjener yang lebih tinggi. Sebagai contoh, BDE99 dan BDE-183 dilaporkan rentan terhadap biodegradasi dan biotransformasi (debromination) menjadi konjener yang lebih ringan seperti BDE$47^{(43)}$, dimana pada ikan mas perubahan ini dapat terjadi melalui jalur debrominasi enzimatik ${ }^{(4)}$. Pada penelitian ini, uji korelasi peringkat Spearman memperlihatkan korelasi linier yang signifikan antara BDE-47 dan konjener PBDEs dengan molekul yang lebih besar, seperti BDE-99, 100,153 dan $154(r=0,808$ sampai $r=0,916$, $p<0,01$, Tabel 5), menunjukkan pengaruh diantaranya dari debrominasi konjener dari molekul PBDE yang lebih besar tersebut.

Tabel 5. Korelasi peringkat Spearman untuk konsentrasi PBDEs di Kerapu.

\begin{tabular}{lcccccccc}
\hline & $\begin{array}{c}\text { BDE- } \\
\mathbf{1 5}\end{array}$ & $\begin{array}{c}\text { BDE- } \\
\mathbf{2 8}\end{array}$ & $\begin{array}{c}\text { BDE- } \\
\mathbf{4 7}\end{array}$ & $\begin{array}{c}\text { BDE- } \\
\mathbf{9 9}\end{array}$ & $\begin{array}{c}\text { BDE- } \\
\mathbf{1 0 0}\end{array}$ & $\begin{array}{c}\text { BDE- } \\
\mathbf{1 5 3}\end{array}$ & $\begin{array}{c}\text { BDE- } \\
\mathbf{1 5 4}\end{array}$ & $\begin{array}{c}\text { Total } \\
\text { BDE }\end{array}$ \\
\hline BDE-15 & 1 & 0,27 & $0,68^{* *}$ & $0,64^{*}$ & $0,70^{* *}$ & $0,77^{* *}$ & $0,72^{* *}$ & $0,73^{* *}$ \\
\hline BDE-28 & 1 & 0,07 & $-0,15$ & $-0,12$ & $-0,06$ & $-0,11$ & $-0,01$ \\
\hline BDE-47 & & 1 & $0,81^{* *}$ & $0,91^{* *}$ & $0,92^{* *}$ & $0,92^{* *}$ & $0,95^{* *}$ \\
\hline BDE-99 & & & 1 & $0,94^{* *}$ & $0,92^{* *}$ & $0,92^{* *}$ & $0,92^{* *}$ \\
\hline BDE-100 & & & & 1 & $0,95^{* *}$ & $0,96^{* *}$ & $0,99^{* *}$ \\
\hline BDE-153 & & & & & 1 & $0,98^{* *}$ & $0,95^{* *}$ \\
\hline BDE-154 & & & & & & 1 & $0,95^{* *}$ \\
\hline $\begin{array}{l}\text { Total } \\
\text { BDE }\end{array}$ & & & & & & & 1 \\
\hline Keterangan: ${ }^{*} p<0.05 ;{ }^{* *} p<0.001$ & & & & &
\end{tabular}

Selain itu, siknifikan korelasi antara BDE-47, 99, 100, 153 dan 154 juga menunjukkan bahwa mereka berasal dari sumber paparan yang sama. Seperti diketahui, BDE-47, 99, 100, 153 dan 154 merupakan konstituen utama dari campuran penta-BDE. Pada Gambar 2 menunjukkan bahwa, 
profil komposisi konjener PBDEs pada kerapu budidaya dan tangkapan lebih mirip dengan profil produk Penta-BDE dari pada campuran OctaBDE maupun Deca-BDE. Lebih-lebih pada profil konjener kerapu hasil tangkapan yang sangat mirip sekali dengan Penta-BDE (Gambar 2), dimana disusun berturut-turut oleh konjener BDE$47>99>100>153=154$. Hal ini menunjukkan bahwa, produk komersial Penta-BDE merupakan sumber utama PBDEs ke pakan ikan dan biota di Indonesia. Meskipun demikian, profil konjener pada kerapu budidaya dimana BDE-154 lebih tinggi proporsinya dibanding BDE-99, 100 dan BDE-153 menunjukkan adanya potensi sumber dari produk PBDE lain, seperti Octa-BDE dan Deca-BDE, yaitu melalui selektif akumulasi maupun debrominasi.

Pakan ikan sebagai sumber paparan ke kerapu budidaya lebih mudah kontak dengan kompartemen sedimen, tanah atau debu yang merupakan matrik penyimpan original sumber pencemar PBDEs. Penelitian terdahulu menunjukkan bahwa, BDE-209 (deca-BDE) dan octa-BDE merupakan konjener yang dominan di sampel sedimen dan tanah di beberapa lokasi di Indonesia ${ }^{(16,17)}$, menunjukan adanya sumber PBDEs dari produk komersial OctaBDE dan DecaBDE yang lebih dominan di Indonesia.

\subsection{Karakterisasi Resiko dan Kajian Paparan}

Karakter dan sifat PBDEs selain persisten dan mudah terakumulasi pada jaringan lemak, adalah juga sangat beracun. Beberapa penelitian menunjukkan bahwa PBDEs memiliki kecenderungan untuk mengganggu hormon tiroid menyebabkan kerusakan neurobehavioral dan kanker pada hewan uji laboratorium, serta perubahan dalam perkembangan jani ${ }^{(45,46)}$. Pada ikan trout (Salvelinus namaycush), PBDEs juga dapat mempengaruhi sistem kekebalan sel-sel tubuh dengan menurunkan viabilitas thymocyte dan meningkatkan apoptosis dan nekrosis hymocytes ${ }^{(4 \pi)}$. Dalam penelitian ini, konsentrasi PBDEs ( $\mathrm{ng} / \mathrm{g}$ berat basah) masih jauh lebih rendah daripada FFTGs untuk standar rujukan PBDEs pada ikan ${ }^{(27)}$ (Tabel 6), menunjukkan bahwa konsentrasi PBDEs belum memberikan efek merugikan pada kesehatan ikan itu sendiri. Sebagai contoh, total PentaBDE konjener pada kerapu budidaya ini masih $10 \%$ dari standar rujukan, sedangkan konsentrasi konjener lain jauh lebih rendah.

Dilain pihak, ikan merupakan sumber protein yang penting bagi kesehatan. Namun demikian, konsumsi ikan merupakan rute paparan PBDEs yang dominan ke manusia $\left.{ }^{(14,15)}\right)$. Karena itu, PBDEs yang terakumulasi dalam ikan menjadi perhatian terhadap efek potensial yang dapat ditimbulkan. Hasil perkiraan asupan harian PBDEs $(D I)$ dari konsumsi kerapu adalah sekitar
0,21 ng/kg BB/hari untuk BDE-47; 0,027 ng/kg $\mathrm{BB} /$ hari untuk $\mathrm{BDE}-99 ; 0,022 \mathrm{ng} / \mathrm{kg} \mathrm{BB} /$ hari untuk BDE-153, dan $0,21 \mathrm{ng} / \mathrm{kg} \mathrm{BB} / \mathrm{hari}$ untuk total PBDEs (Tabel 6), dengan asumsi bahwa ratarata orang dewasa Indonesia memiliki berat badan (BB) $60 \mathrm{~kg}$ dan mengkonsumsi ikan 43,88

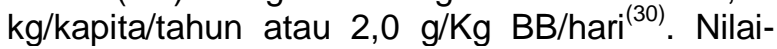
nilai ini masih jauh di bawah standar rujukan, baik RfDs dari US-EPA ${ }^{(28)}$ sebesar $100-2000 \mathrm{ng}$ $\mathrm{PBDEs} / \mathrm{kg} \mathrm{BB} /$ hari (tergantung konjener) maupun nilai MRL dari ASTDR sebesar $0,00006 \mathrm{mg} / \mathrm{kg}$ BW/hari (60 ng/kg BB/hari) ${ }^{(29)}$.

Tabel 6. Konsentrasi PBDEs pada kerapu, FFTGs (ng/g berat basah), DI (ng PBDEs/kg BB/hari), RfDs (ng PBDEs/kg $\mathrm{BB} /$ hari) dan $\mathrm{HQ}$ pada penelitian ini.

\begin{tabular}{|c|c|c|c|c|c|}
\hline PBDEs & Konsentrasi & $\begin{array}{l}\text { FFT } \\
\text { Gs }\end{array}$ & DI & RfDs & HQ \\
\hline $\begin{array}{l}\text { BDE- } \\
28\end{array}$ & $\begin{array}{c}0,0018 \\
(0,0009- \\
0,0028)\end{array}$ & 120 & td & - & - \\
\hline $\begin{array}{l}\text { BDE- } \\
47\end{array}$ & $\begin{array}{c}0,035 \\
(0,064-0.14)\end{array}$ & 88 & $\begin{array}{c}0,071 \\
(0.050- \\
0,078)\end{array}$ & 100 & $\begin{array}{c}7,1 \times 10^{-4} \\
(5,0-11) \times 10^{-4}\end{array}$ \\
\hline $\begin{array}{l}\text { BDE- } \\
99\end{array}$ & $\begin{array}{c}0,014 \\
(0,008-0,018)\end{array}$ & 1,0 & $\begin{array}{c}0,027 \\
(0.014- \\
0,035)\end{array}$ & 100 & $\begin{array}{c}2,7 \times 10^{-4} \\
(1,4-3,5) \times 10^{-4}\end{array}$ \\
\hline $\begin{array}{l}\text { BDE- } \\
100\end{array}$ & $\begin{array}{c}0,020 \\
(0,011-0,027)\end{array}$ & 1,0 & td & - & - \\
\hline $\begin{array}{l}\text { BDE- } \\
153\end{array}$ & $\begin{array}{c}0,011 \\
(0,006-0,014)\end{array}$ & 420 & $\begin{array}{c}0,022 \\
(0,012- \\
0,026)\end{array}$ & 200 & $\begin{array}{c}1,1 \times 10^{-4} \\
(0,60-1,3) \times \\
10^{-4}\end{array}$ \\
\hline $\begin{array}{l}\text { Penta- } \\
\text { BDE }\end{array}$ & $\begin{array}{c}0,10 \\
(0,064-0,14)\end{array}$ & 1,0 & $\begin{array}{c}0,21 \\
(0,13-0,29)\end{array}$ & 2000 & $\begin{array}{c}1,0 \times 10^{-4} \\
(0,64-1,4) \times \\
10^{-4}\end{array}$ \\
\hline $\begin{array}{l}\text { Octa- } \\
\text { BDE }\end{array}$ & td & - & - & 3000 & - \\
\hline $\begin{array}{l}\text { BDE- } \\
209\end{array}$ & td & - & - & 7000 & - \\
\hline
\end{tabular}

Lebih lanjut, $\mathrm{HQ}$ yang merupakan nilai resiko, memperlihatkan nilai yang sangat jauh dibawah nilai 1 (pada penelitian ini maksimal 0,0011 untuk BDE-47) yang menunjukkan batas keamanan yang masih lebar (large margin of safety) dari mengkonsumsi kerapu. Semua ini menyiratkan bahwa konsumsi ikan dengan konsentrasi PBDEs saat ini memiliki risiko minimal untuk kesehatan orang Indonesia. Sebelumnya juga dilaporkan bahwa, estimasi asupan harian dari PCBs, dichlorodiphenyltrichloroethane (DDTs), chlordanes (CHLs), hexachlorocyclohexanes $(\mathrm{HCHs})$ dan hexachlobenzene (HCB) dari konsumsi ikan untuk orang Indonesia juga masih jauh lebih rendah dari standar asupan harian yang masih diperbolehkan (Acceptable Daily Intake - $A D I$ ) dan rujukan RfDs dari FAO/WHO, Health Canada dan US-EPA ${ }^{(49)}$. Hasil penelitian di Amerika dengan tingkat PBDEs tertinggi di dunia juga belum menemukan hubungan yang jelas antara konsentrasi serum PBDE dan hormon tiroid pada sampel populasi manusia ${ }^{(48)}$.

Dengan demikian, potensi dampak yang dapat ditimbulkan dari konsentrasi PBDEs pada penelitian ini kemungkinan masih jauh di bawah 
manfaat kesehatan yang dihasilkan dari konsumsi ikan. Ikan kerapu mengandung senyawa-senyawa bermanfaat, seperti asam lemak, omega-3, vitamin ( $D$ dan B2), fosfor, kalsium dan mineral (zat besi, seng, yodium, magnesium dan kalium) yang sangat berguna bagi kesehatan. Sebagai contoh, rantai panjang asam lemak tak jenuh ganda n-3 (long chain polyunsaturated $n-3$ fatty acids) merupakan senyawa yang memegang peranan penting dalam pencegahan penyakit jantung ${ }^{(50)}$ ). Lebih lanjut, $\mathrm{FAO} / \mathrm{WHO}^{(51)}$ menggaris bawahi bahwa konsumsi ikan, dapat mengurangi risiko kematian akibat penyakit jantung koroner (PJK). Dinyatakan bahwa, konsentrasi methylmercury terkait risiko PJK dan dioksin terkait potensi risiko kanker, masih jauh di bawah manfaat kesehatan yang disebabkan konsumsi ikan ${ }^{(51)}$. Demikian pula, Norwegian Scientific Committee for Food Safety (VKM) menyimpulkan bahwa manfaat makan ikan jelas-mempertimbangkan risiko yang diabaikan berkaitan dengan tingkat kontaminan saat ini ${ }^{(52)}$. Namun demikian, pengetahuan tentang kadar polutan, jenis biota yang dikonsumsi, frekuensi konsumsi dan ukuran porsi sangat penting untuk menyeimbangkan manfaat kesehatan dan risiko yang dapat ditimbulkan dari konsumsi ikan. Karena itu, informasi yang menyeluruh terkait jenis polutan beracun, tersebar luas dilingkungan dan berbahaya pada produk seafood multak diperlukan, seperti POPs, perfluorinated compounds (PFCs), pharmaceuticals dan personal care products (PPCPs), brominated flame retardants (BFRs), logam berat, mikroplastik, toxin dari harmful algal blooms dan sebagainya.

\section{KESIMPULAN}

PBDEs terdeteksi pada semua sampel dengan dengan kandungan total sebesar 4,2 (2,6-6,2 ng/g berat lemak) pada kerapu budidaya, $0,90(0,20-1,6 \mathrm{ng} / \mathrm{g}$ berat lemak) pada kerapu liar dan $(1,2-7,3 \mathrm{ng} / \mathrm{g}$ berat lemak) pada pakan ikan, serta $0,20 \mathrm{ng} / \mathrm{g}$ berat lemak pada minyak suplemen. Komposisi PBDEs berturut-turut adalah BDE-47>154>100>99>153 pada ikan kerapu budidaya, BDE-47>99>100>153=154, pada kerapu liar dan BDE-47>154>100>99>153 pada pakan ikan. Sedangkan estimasi paparan harian total PBDEs ke orang Indonesia melalui konsumsi ikan kerapu adalah sebesar 0,21 ng PBDEs/kg berat badan/hari. Hasil penelitian ini menunjukkan bahwa derajat kontaminasi PBDEs pada ikan kerapu dan estimasi paparan dari konsumsi kerapu ke orang Indonesia masih rendah.

\section{PERSANTUNAN}

Penelitian ini dapat terlaksana melalui kerjasama antara BPPT dengan Center for Marine Environental Studies (CMES), Ehime University, Jepang dalam kerangka MOU tentang Kerjasama IImiah dan Teknis dalam Perlindungan Lingkungan Perairan Laut. Penulis mengucapkan terima kasih kepada Prof. Shinsuke Tanabe, Dr. Tomohiko Isobe dan Dr. Shin Takahashi atas pemanfaatan es-Bank untuk penyimpanan sampel dan analisis PBDEs di Laboratorium Kimia Lingkungan dan Toksikologi, CMES. Ucapan terima kasih juga disampaikan kepada Ir. Muawanah dan Ir. Paulus Hartono dari BBBL Lampung yang memfasilitasi dalam pengambilan sampel di lapangan.

\section{DAFTAR PUSTAKA}

1. Anonymous. (2014). Value chain analysis of marine fish aquaculture in Indonesia: business opportunities for Norwegian Companies. Innovation Norway, Jakarta, Spire Research and Consultant, p. 154.

2. Halim, D., Juanry. (2014). Indonesia's aquaculture industry: Key sectors for future growth. Jakarta, Ipsos Business Consulting, p. 235.

3. Sadovy, Y. (2000). Regional survey for fry/fingerling supply and current practices for grouper mariculture: Evaluating current status and long-term prospects for grouper mariculture in Southeast Asia. Final report to the collaborative APEC grouper research and development network (FWG 01/99).

4. Prihadi, D.J. (2011). Pengaruh jenis dan waktu pemberian pakan terhadap tingkat kelangsungan hidup dan pertumbuhan kerapu macan (Epinephelus fuscoguttatus) dalam karamba jaring apung di Balai Budidaya Laut Lampung. Jurnal Akuatika, 2(1), 1-11.

5. Sari, S.M. 2018. Produksi Ikan Kerapu 2017 Melompat. Bisnis Indonesia. industri.bisnis. com/read/20180114/99/726346/produksiikan-kerapu-2017-melompat (Akses 5 Juli 2018).

6. Gu, S-Y., Ekpeghere, K. I., Kim, H-Y., Lee, IS., Kim, D-H., Cho, G., Oh, J-E. (2017). Brominated flame retardants in marine environment focused on aquaculture area: Occurrence, source and bioaccumulation. Science of the Total Environment, 601-602, 1182-1191.

7. Jacobs, M.N., Covaci, A., Schepens, P. (2002). Investigation of selected persistent organic pollutants in farmed Atlantic Salmon (Salmo salar), salmon aquaculture feed, and 
fish oil components of the feed. Environmental Science \& Technology, 36, 2797-2805.

8. Easton, M. D. L., Luszniak, D., Von der Geest, E. (2002). Preliminary examination of contaminant loadings in farmed salmon, wild salmon and commercial salmon feed. Chemosphere, 46(7), 1053-1074.

9. Hites, R.A., Foran, J.A., Schwager, S.J., Knuth, B.A., Hamilton, M.C., Carpenter, D.O. (2004a). Global assessment of polybrominated diphenyl ethers in farmed and wild salmon. Environmental Science \& Technology, 38, 4945-4949.

10. de Wit, C.A.. (2002). An overview of brominated flame retardants in the environment. Chemosphere, 46(5), 583-624.

11. La Guardia, M.J., Hale, R.C., Harvey, E. (2006). Detailed polybrominated diphenyl ether (PBDE) congener composition of the widely used penta-, octa-, and deca-PBDE technical flame-retardant mixtures. Environmental Science \& Technology, 40, 6247-6254.

12. KLH. (2014). Review and Update of National Implementation Plan for Stockholm Convention on Persistent Organic Pollutants in Indonesia. Kementerian Lingkungan Hidup, 130 hal.

13. UNEP. (2010). Stockholm Convention on Persistent Organic Pollutants (POPs). The Secretariat of Stockholm Convention, p. 65.

14. Domingo, J.L. (2012). Polybrominated diphenyl ethers in food and human dietary exposure: a review of the recent scientific literature. Food Chemistry and Toxicology, 50(2), 238-249.

15. Na, S., Kim, M., Paek, O., Kim, Y. (2013). Dietary assessment of human exposure to PBDEs in South Korea. Chemosphere, 90 (5), 1736-1741.

16. Ilyas, M., Sudaryanto, A., Setiawan, I.E., Riyadi, A.S., Isobe, T., Ogawa, S., Takahashi, S., Tanabe, S. (2011a). Characterization of polychlorinated biphenyls and brominated flame retardants in surface soils from Surabaya, Indonesia. Chemosphere, 83(6), 783-91.

17. Eguchi, A., Isobe, T., Ramu, K., Tue, HM., Sudaryanto, A., Devanathan, G., Viet, PH., Tana, RS., Takahashi, S., Subramanian, A., Tanabe, S. (2012). Soil contamination by brominated flame retardants in open waste dumping sites in Asian developing countries. Chemosphere, 90(9), 2365-237.

18. Ilyas, M., Sudaryanto, A., Setiawan, I.E., Riyadi, A.S., Isobe, T., Ogawa, S., Takahashi, S., Tanabe, S. (2011b). Characterization of polychlorinated biphenyls and brominated flame retardants in sediments from riverine and coastal waters of Surabaya, Indonesia. Marine Pollution Bulletin, 62(1), 89-98.

19. Ilyas, M., Sudaryanto, A., Setiawan, I.E., Riyadi, AS., Isobe, T., Tanabe, S. (2013). Characterization of polychlorinated biphenyls and brominated flame retardants in sludge, sediment and fish from municipal dumpsite at Surabaya, Indonesia. Chemosphere, 93(8), 1500-1510.

20. Sudaryanto, A., Isobe, T., Tanabe, S. (2012). Trophodynamic accumulation of brominated flame retardants in biota of Jakarta Bay. Majalah IImiah Widyariset, 15(2), 313-321.

21. Sudaryanto, A., Takahashi, S., Hartono, P., Muawanah and Tanabe, S. (2008). Geographical distributions and accumulation features of polybrominated diphenyl ethers (pbdes) in human breast milk from Indonesia. Environmental Pollution, 151(1), 130-138.

22. Tanabe, S. 2006. Environmental Specimen Bank in Ehime University (es-BANK), Japan for global monitoring. Journal of Environmental Monitoring, 8(8), 782-90.

23. Ueno, D., Kajiwara, N., Tanaka, H., Subramanian, A., Fillmann, G., Lam, P.K.S., Zheng, G.J., Muchitar, M., Razak, H., Prudente, M., Chung, K.H., Tanabe, S. (2004). Global pollution monitoring of polybrominated diphenyl ethers using skipjack tuna as a bioindicator. Environmental Science \& Technology, 38, 2312-2316.

24. Tomy, G.T., Halldorson, T., Danell, R., Law, $\mathrm{K}$, Arsenault, G., Alaee, M., Maclnnis, G., Marvin, C.H. (2004). Refinements to the diastereo-isomer specific method for the analysis of hexabromocyclododecane. Rapid Communica-tion Mass Spectrometry, 19, 2819-2826.

25. Xian, Q., Ramu, K., Isobe, T., Sudaryanto, A., Liu, X., Gao, Z., Takahashi, S., Yu, H. and Tanabe, S. (2008). Levels and body distribution of polybrominated diphenyl ethers (PBDEs) and hexabromocyclododecanes (HBCDs) in 
freshwater fishes from the Yangtze River, China. Chemosphere, 71(2), 268-276.

26. IBM Corp. (2016). IBM SPSS Statistics for Windows, Version 24.0. Armonk, NY: IBM Corp. (Released 2016).

27. Environment Canada. 2013. Canadian Environmental Protection Act, Federal Environmental Quality Guidelines for Polybrominated Diphenyl Ethers (PBDEs). Environment Canada, p. 25. http://www.ec.gc.

ca/eseees/default.asp?lang=En\&n=05DF7A 37-1 (Akses 5 September 2018).

28. US-EPA. 2017. Technical Fact Sheet PBDEs. United States Environmental Protection Agency (US-EPA), Office of Land and Emergency Management, EPA 505-F17-015, November 2017. https://www.epa.gov/ sites/production/files/201403/documents/ffrro factsheet_contaminant_perchlorate_january 2014_final_0.pdf (Akses 5 September 2018).

29. ATSDR. 2018. Minimal Risk Levels (MRLs) for Hazardous Substances. Agency for Toxic Substances and Disease Registry, Atlanta. https://www.atsdr.cdc.gov/mrls/mrllist.asp\#1 83tag (Akses 15 September 2018).

30. KKP. 2018. Sistem Informasi Diseminasi Data dan Statistik Kelautan dan Perikanan: Kelautan dan Perikanan Dalam Angka Tahun 2012-2016. Kementerian Perikanan dan Kelautan (KKP). http://statistik.kkp.go.id/ sidatik-dev/index.php?m=5 (Akses 1 Juli 2018).

31. Tittlemier, S., A., Forsyth, D., Breakell, K., Verigin, V., Ryan, J.J., Hayward, S. (2004). Polybrominated diphenyl ethers in retail fish and shellfish samples purchased from Canadian markets. Journal of Agricultural and Food Chemistry, 52(25), 7740-7745.

32. Montory, M., Barra, R. (2006). Preliminary data on polybrominated diphenyl ethers (PBDEs) in farmed fish tissues (Salmo salar) and fish feed in Southern Chile. Chemosphere, 63, 1252-1260.

33. Staskal, D.F., Scott, L.L., Haws, L.C., Luksemburg, W.J., Birnbaum, L.S. Urban, J.D., Williams, E.S., Paustenbach, D.J., Harris, M.A. (2008). Assessment of polybrominated diphenyl ether exposures and health risks associated with consumption of southern Mississippi catfish. Environmental Science
Technology,42(17), 675-6761.
34. Shaw, S.D., Berger, M.L., Brenner, D., Carpenter, D.O., Kannan, K. (2008). Polybro-minated diphenyl ethers (PBDEs) in farmed and wild salmon marketed in the Northeastern Chemosphere,71(8), 1422-1431.

35. Klasing, S., dan Brodberg, R. (2011). Fish contaminant goals and advisory tissue levels for contaminants in sport fish: PBDEs. Pesticide and Environmental Toxicology Branch Office of Environmental Health Hazard Assessment California. Environmental Protection Agency. California, USA. p. 40.

36. Bianco, G., Novario, G., Anzilotta, G., Palma, A., Mangone, A., Cataldi, T.R. (2010). Polybrominated diphenyl ethers (PBDEs) in Mediterranean mussels (Mytilus galloprovincialis) from selected Apulia coastal sites evaluated by GC-HRMS. Journal of Mass Spectrometry, 45(9),1046-1055.

37. Bethune, C., Julshamn, K., Lundebye, A.K. (2005). A preliminary comparison of polybrominated diphenyl ethers relative to lipid content and to levels of dioxins and dioxin like polychlorinated biphenyls in Norwegian farmed Atlantic salmon (Salmo salar). International Journal of Food Science and Technology, 40, 143-148.

38. Russell, R. W., Gobas, F. A. P. C., Haffner, G. D. (1999). Role of chemical and ecological factors in trophic transfer of organic chemicals in aquatic food webs. Environmental Toxicology and Chemistry, 18( 6), 1250-1257.

39. FAO. (2019). Atlantic Salmon - Feed Production. Food and Agricultural Organization of United Nations. http://www.fao.org/fishery/ affris/speciesprofiles/atlantic-salmon/feedproduction/en/ (Akses 20 November 2018).

40. Rimmer, M.A., Sudja, W., Indradjaja, D.D., Giri, N.A., Laining, A. (2017). Compound feeds for grouper aquaculture - why has adoption been so poor? Aqua Culture Asia Pacific Magazine, 12(5), 25-28.

41. Asplund, L., Athanasiadou, M., Sjodin, A., Bergman, A., Borjeson, H. (1999). Organohalogen substances in muscle, egg and blood from healthy Baltic salmon (Salmo salar) and Baltic salmon that produced offspring with the M74 syndrome. Ambio, 28,: 67-76.

42. Boon, J.P., Lewis, W.E., Tjoen-A-Choy, M.R., Allchin, C.R., Law, R.J., de Boer, J., 
Ten Hallers-Tjabbes, C.C., Zegers, B.N. (2002). Levels of polybrominated diphenyl ether (PBDE) flame retardants in animals representing different trophic levels of the North Sea food web. Environmental Science and Technology, 36, 4025-4032.

43. Stapleton, H.M., Letcher, R.J., Baker, J.E. (2004). Debromination of polybrominated diphenyl ether congeners BDE 99 and BDE 183 in the intestinal tract of the common carp (Cyprinus carpio). Environmental Science and Technology, 38(4),1054-1061.

44. Benedict, R.T., Stapleton, H.M., Letcher, R.J., Mitchelmore, C.L. (2007). Debromination of polybrominated diphenyl ether-99 (BDE- 99) in carp (Cyprinus carpio) microflora and microsomes. Chemosphere, 69(6), 987-993.

45. Eriksson, P., Viberg, $\mathrm{H}_{\text {., }} \quad$ Fredrikson, A. (2001). Brominated flame retardant: a novel class of developmental neurotoxicants in our environment? Environmental Health Perspectives, 109, 903-908.

46. Gill, U., Chu, I., Ryan, J.J., Feeley, M. (2004). Polybrominated diphenyl ethers: human tissue levels and toxicology. Reviews of Environ-mental Contamination and Toxicolo-gy, 183: 55-97.

47. Birchmeier, K.L., Smith, K.A., PassinoReader, D.R., Sweet, L.I., Chernyak, S.M., Adams, J.V., Omann, G.M. (2005). Effects of selected polybrominated diphenyl ether flame retardants on lake trout (Salvelinus namaycush) thymocyte viability, apoptosis, and necrosis. Environmental Toxicology and Chemistry, 24, 1518-1522.

48. Mazdai, A., Dodder, N.G., Abernathy, M.P. R Polybrominated diphenyl ethers in maternal and fetal blood samples. Environmental Health Perspectives, 111, 1249-1252.

49. Sudaryanto, A., Monirith, I., Kajiwara, N., Hartono, P., Muawanah, Omori, K., Takeoka, $\mathrm{H}$. and Tanabe, S. (2007). Levels and distribution of organochlorines in fish from Indonesia. Environment International, 33(6), 750-758.

50. He, K., Song, Y., Daviglus, M.L., Liu, K., Van Horn, L., Dyer, A.R., Greenland, P. (2004). Accumulated evidence on fish consumption and coronary heart disease mortality: a meta-analysis of cohort studies. Circulation, 109, 2705-2711.

51. FAO/WHO. (2011). Report of the joint $\mathrm{FAO}$ WHO expert consultation on the risks and benefits of fish consumption. Rome, Food and Agriculture Organization of the United Nations; Geneva, World Health Organization, $50 \mathrm{pp}$.

52. VKM. (2014). Benefit-risk assessment of fish and fish products in the Norwegian diet - an update. Scientific Opinion of the Scientific Steering Committee. VKM Report 15 [293 pp], ISBN: 978-82-8259-159-1, Oslo, Norway. 